UDC 347.9:347.157.1

LBC 67.410.101

\title{
JUVENILES AS MEMBERS OF THE CIVIL PROCEDURE
}

\author{
Antonina V. Goncharova \\ Volgograd Institute for the Humanities, Volgograd, Russian Federation
}

\begin{abstract}
Introduction: a juvenile is not always aware of the possibility of exercising his rights and legally protected interests. In most cases when a legal issue arises a minor turns for help to his parents (or persons substituting them). However, there are cases when there is no one for the child to turn for (no parents, parents-alcoholics, lack of understanding, etc.). The aim is to carry out the theoretical analysis of the involvement of minors in proceedings, based on the analysis of substantive law and procedural law. With that in mind, the objectives of the study are the following: a comprehensive study of a juvenile's involvement in civil proceedings as a person involved in the case. Having analyzed the legislation the author has concluded on the need to make the amendment to the Civil Procedure Code which regulates the participation of minors in civil proceedings.
\end{abstract}

Keywords: minors, interrogation (questioning) of minor witnesses, involvement of minors in trials, civil procedure.

УДК 347.9:347.157.1

ББК 67.410 .101

\section{НЕСОВЕРШЕННОЛЕТНИЕ КАК УЧАСТНИКИ ГРАЖДАНСКОГО ПРОЦЕССА}

\author{
Антонина Викторовна Гончарова \\ Волгоградский гуманитарный институт, г. Волгоград, Российская Федерация
}

\begin{abstract}
Введение: несовершеннолетний не всегда знает о возможности реализации своих прав и законных интересов. В большинстве случаев при возникновении проблемы правового характера несовершеннолетний обращается за помощью к родителям (либо лицам, их замещающим). Однако бывают случаи, когда ребенку не к кому обратиться (отсутствие родителей, родители-алкоголики, отсутствие взаимопонимания и т. д.), тогда закон допускает участие несовершеннолетних в рассмотрении дел судами. Цель состоит в проведении теоретического анализа участия несовершеннолетних в суде на базе анализа норм материального и процессуального права. Учитывая это, задачей исследования выступает всестороннее изучение участия несовершеннолетнего в гражданском процессе в качестве лица, участвующего в деле. Проанализировав законодательство, сделан вывод о необходимости внесения в Гражданский процессуальный кодекс нормы, определяющей участие несовершеннолетних в рассмотрении судами гражданских дел.

Ключевые слова: несовершеннолетние, опрос (допрос) несовершеннолетних свидетелей, участие несовершеннолетних в суде, гражданский процесс.
\end{abstract}

\section{Введение}

В соответствии со ст. 56 Семейного кодекса РФ (далее - СК РФ) ребенок имеет خे право на защиту своих прав и законных интересов [5]. Защита прав и законных интересов ребенка осуществляется родителями либо 。̊. лицами, их замещающими (усыновителями, Æ्ञ опекунами, попечителями...). Однако защиту 흥 прав и законных интересов ребенка не могут () осуществлять: лица, лишенные родительских прав; граждане, у которых он отобран по решению суда либо органом опеки и попечительства; лица, признанные недееспособными. Не могут выступать в роли защитника прав и законных интересов своего ребенка также граждане, чья дееспособность ограничена из-за злоупотребления спиртными напитками или наркотическими средствами. В этих случаях закон предусматривает защиту прав несовершеннолетних органом опеки и попечительства, прокурором, судом. 
Несовершеннолетний, признанный в соответствии с законом полностью дееспособным до достижения 18 лет, имеет право самостоятельно осуществлять свои права и обязанности, в том числе право на защиту (ст. 60 Конституции РФ [3]; ст. 21 Гражданского кодекса РФ (далее - ГК РФ) [1]).

\section{Обращение несовершеннолетних в суд за защитой своих прав и законных интересов}

Во-первых, в соответствии со ст. 56 СК РФ и ст. 26 ГК РФ ребенок вправе самостоятельно обращаться за защитой в орган опеки и попечительства, а по достижении возраста 14 лет в суд:

- при нарушении его прав и законных интересов;

- при невыполнении или при ненадлежащем выполнении родителями (одним из них) обязанностей по воспитанию, образованию ребенка; правами.

- при злоупотреблении родительскими

А также в соответствии со ст. 62 СК РФ несовершеннолетние родители имеют право:

- признавать и оспаривать свое отцовство и материнство на общих основаниях;

- требовать по достижении ими возраста 14 лет установления отцовства в отношении своих детей в судебном порядке.

Во-вторых, ребенок вправе выражать свое мнение при решении в семье любого вопроса, затрагивающего его интересы, а также быть заслушанным в ходе любого судебного или административного разбирательства. В соответствии со ст. 57 СК РФ учет мнения ребенка, достигшего возраста 10 лет, обязателен. Органы опеки и попечительства или суд могут принять решение только с согласия ребенка, достигшего возраста 10 лет, в случаях:

- изменения фамилии и/или имени ребенка;

- восстановления родителей в родительских правах;

- усыновления;

- отмены усыновления;

- передачи в приемную семью.

Однако законом установлены исключения в случаях, когда это противоречит интересам несовершеннолетнего (например, если имеет место стремление ребенка при опре- делении судом его места жительства остаться жить с родителем-алкоголиком).

\section{Участие несовершеннолетнего \\ в судебном разбирательстве по гражданским делам}

В Постановлении Пленума Верховного Суда РФ указано, что если при разрешении спора суд придет к выводу о необходимости опроса несовершеннолетнего, то следует предварительно выяснить мнение органа опеки и попечительства о том, не окажет ли неблагоприятного воздействия на ребенка его присутствие в суде [4].

В соответствии со ст. 179 Гражданского процессуального кодекса РФ с учетом возрастных особенностей подростков, а также для установления контакта с допрашиваемым в судебное заседание приглашается педагог [2]. В качестве педагога приглашается специалист с педагогическим образованием, имеющий опыт работы с подростками.

При наличии серьезных оснований полагать, что в присутствии кого-либо из лиц, находящихся в зале суда, несовершеннолетний свидетель не сможет дать правдивые и полные показания, суд может вынести определение об удалении такого лица из зала судебного заседания. В этом случае удаленному из зала лицу - участнику дела по его возвращении сообщаются данные свидетелем показания и предоставляется возможность задать ему вопросы.

По общему правилу свидетели после допроса остаются в зале судебного заседания. Однако несовершеннолетние, не достигшие возраста 16 лет, по окончании их допроса удаляются из зала судебного заседания. Оставление свидетеля, не достигшего 16 лет, в зале судебного заседания после дачи им показания возможно лишь при исключительных обстоятельствах, например, при необходимости повторного допроса, получения дополнительных сведений в связи с исследованием письменных или вещественных доказательств и т. п.

\section{Вывод}

Недостатком является отсутствие в законе конкретной нормы, регулирующей механизм обращения несовершеннолетнего в суд и 
его участие в процессе в качестве истца, в связи с чем на практике судьи часто отказывают несовершеннолетним истцам в праве на защиту, ссылаясь на их неполную дееспособность. Как было сказано, СК РФ закрепляет право несовершеннолетних обращаться в суд для защиты своих прав и законных интересов по достижении ими четырнадцати лет. В этой связи существует необходимость внесения в Гражданский процессуальный кодекс нормы, определяющей участие несовершеннолетних в рассмотрении судами гражданских дел.

\section{СПИСОК ЛИТЕРАТУРЫ}

1. Гражданский кодекс Российской Федерации (часть первая) от 30 нояб. 1994 г. № 51-Ф3 // Собрание законодательства РФ. - 1994. - 5 дек. № 32. - Ст. 3301 .

2. Гражданский процессуальный кодекс Российской Федерации от 14 нояб. 2002 г. № 138-Ф3 // Собрание законодательства РФ. - 2002. - 18 нояб. № 46. - Ст. 4532.

3. Конституция Российской Федерации : (принята всенар. голосованием 12 дек. 1993 г.) // Собрание законодательства РФ. - 2014. - 4 авг. - № 31. -Ст. 4398.

4. Постановление Пленума Верховного Суда РФ «О применении судами законодательства при разрешении споров, связанных с воспитанием детей» от 27 мая 1998 г. № 10 (п. 3) // Бюллетень Верховного Суда РФ. - 1998. - № 7.

5. Семейный кодекс Российской Федерации от 29 дек. 1995 г. № 223-Ф3 // Собрание законодательства РФ. - 1996. - 1 янв. - № 1. - Ст. 16.

6. Филиппов, П. М. Судебная реформа и ее движение / П. М. Филиппов // Вестник Волгоградского государственного университета. Серия 5, Юриспруденция. - 2015. - № 4 (29). - С. 123-129.

\section{REFERENCES}

1. Grazhdanskiy kodeks Rossiyskoy Federatsii (chast pervaya) ot 30.11.1994 № 51-FZ [The Civil Code of the Russian Federation (Part One) of November 30, 1994 no. 51-FL]. Sobranie zakonodatelstva RF [Collected Legislation of the Russian Federation], 1994, December 5 (no. 32), art. 3301.

2. Grazhdanskiy protsessualnyy kodeks Rossiyskoy Federatsii ot 14.11.2002 № 138-FZ [Civil Procedure Code of the Russian Federation of November 14, 2002 no. 138-FL]. Sobranie zakonodatelstva RF [Collected Legislation of the Russian Federation], 2002, November 18 (no. 46), art. 4532.

3. Konstitutsiya Rossiyskoy Federatsii: (prinyata vsenarodnym golosovaniem 12.12.1993) [The Constitution of the Russian Federation: (Adopted by the All-People Voting on December 12, 1993)]. Sobranie zakonodatelstva RF [Collected Legislation of the Russian Federation], 2014, August 4 (no. 31), art. 4398.

4. Postanovlenie Plenuma Verkhovnogo Suda $\mathrm{RF} « \mathrm{O}$ primenenii sudami zakonodatelstva pri razreshenii sporov, svyazannykh s vospitaniem detey» ot 27.05.1998 № 10 (p. 3) [Resolution of the Plenum of the Supreme Court of the Russian Federation "On the Application of the Law by the Courts in the Resolution of Disputes Relating to the Children Upbringing" of May 27, 1998 no. 10 (item 3)]. Bulleten Verkhovnogo Suda RF, 1998, no. 7.

5. Semeynyy kodeks Rossiyskoy Federatsii ot 29.12.1995 № 223-FZ [The Family Code of the Russian Federation of December 29, 1995 no. 223-FL]. Sobranie zakonodatelstva RF [Collected Legislation of the Russian Federation], 1996, January 1 (no. 1), art. 16.

6. Filippov P.M. Sudebnaya reforma i ee dvizhenie [Judicial Reform and Its Motion]. Vestnik Volgogradskogo gosudarstvennogo universiteta. Seriya 5, Yurisprudentsiya [Science Journal of Volgograd State University. Jurisprudence], 2015, no. 4 (29), pp. 123-129.

\section{Information About the Author}

Antonina V. Goncharova, Candidate of Juridical Sciences, Associate Professor, Dean of the Law Department, Volgograd Institute for the Humanities, Gribanova St., 12, 400119 Volgograd, Russian Federation, AntoninaVS@mail.ru.

\section{Информация об авторе}

Антонина Викторовна Гончарова, кандидат юридических наук, доцент, декан юридического факультета, Волгоградский гуманитарный институт, ул. Грибанова, 12, 400119 г. Волгоград, Российская Федерация, AntoninaVS@mail.ru. 